\section{Upper airway oedema following autologous blood transfusion from a wound drainage system}

Russell Woda Do, John E. Tetzlaff MD

\begin{abstract}
We report a case of a 70-yr-old white woman who underwent a revision of a total hip arthroplasty under general anaesthesia. The intraoperative course was stable without any complications and the estimated blood loss was $2500 \mathrm{ml}$. The patient received an autologous transfusion of blood from a wound drainage system in the recovery room. The transfusion was followed immediately by marked respiratory distress and upper ainway oedema. She required emergency tracheal intubation and mechanical pulmonary ventilation. A coagulopathy also developed which was treated and resolved within $12 \mathrm{hr}$ of the capillary leak phenomenon. The trachea was extubated on the first postoperative day and she had an uneventful course until discharge from the hospital two days later. We discuss the possible, aetiology of such a reaction to autologous blood including complement and platelet activation. It is suggested that reinfusion of nonwashed shed blood from a wound drainage system may present a hazard even though the fluid was autologous in origin.
\end{abstract}

Le cas présent concerne la revision, sous anesthésie générale d'une arthroplastie totale de la hanche chez une femme de race blanche de 70 ans. La période peropératoire a été stable, sans complication, avec une perte sanguine évaluée à $2500 \mathrm{ml}$. Une transfusion sanguine autologue provenant d'un système de drainage de la plaie a été administrée à la salle de réveil. Une détresse respiratoire marquée ainsi qu'un oedème des voies

\section{Key words}

TRANSFUSION: autologous, complications.

From the Department of General Anesthesiology, Cleveland Clinic Foundation, 9500 Euclid Avenue, Cleveland, Ohio 44195.

Address correspondence to: Dr. John E. Tetzlaff, Department of General Anesthesiology, Cleveland Clinic Foundation, 9500 Euclid Avenue, Cleveland, Ohio 44195-5001.

Accepted for publication 4th November, 1991. respiratoires supérieures sont apparus immédiatement après la transfusion, nécessistant une intubation endotrachéale urgente et une ventilation pulmonaire mécanique. Une coagulopathie s'est également développée et disparut après traitment moins de douze heures après le début de ce phénomène de fuite capillaire. Après le retrait du tube endotrachéal au premier jour postopératoire, on ne nota aucun incident jusqu'au congé de la patiente deux jours plus tard. Nous discutons de l'étiologie possible d'une telle réaction au sang autologue, y compris l'activation des compléments et des plaquettes. La réinfusion de sang non lavé provenant d'un système de drainage de la plaie peut présenter un risque même si le liquide était d'origine autologue.

Acute respiratory failure following blood transfusion in the perioperative period has been reported frequently. It is an important cause of perioperative morbidity and prompt recognition and therapeutic intervention are important. ${ }^{1-8}$ If the use of blood salvage manoeuvres, including use of autologous blood, were to be increased, this incidence should be reduced. However, an example of respiratory distress which followed transfusion of nonwashed, shed blood will be described.

\section{Case report}

A 70-yr-old white woman with intractable pain was scheduled to undergo revision total hip arthroplasty. Preoperative evaluation revealed a past medical history of hypertension, hypothyroidism, and seizure disorder. The patient had a cerebral vascular accident $12 \mathrm{yr}$ before surgery which was followed by a seizure disorder. She was well controlled on phenytoin, tegretol, and valproic acid. Additional medication included synthroid, dipyridamole, meclazine and aspirin. She had had previous surgery for a breast mass, open reduction and internal fixation of a left hip fracture, and total hip arthroplasty which was performed five years before the present admission, The initial hip arthroplasty was complicated by intraoperative and perioperative bleeding which required multiple transfusions of blood products. She denied any 
history of drug allergy. The physical examination was unremarkable. A preoperative chest $x$-ray showed tortuosity of the descending thoracic aorta, but was otherwise normal. An ECG showed normal sinus rhythm and was otherwise normal. Preoperative laboratory work consisting of a complete blood count, prothrombin time, partial thromboplastin time and blood chemistry were normal. The $\mathrm{T}_{3}$ level was $89(94-170 \mathrm{ng} \%)$ and the TSH 8.2 $\left(0.4-5.5 \mu \mathrm{g} \cdot \mathrm{ml}^{-1}\right)$. The valproic acid concentration was 34.9 (normal $80-150 \mu \mathrm{g} \cdot \mathrm{ml}^{-1}$ ). Bleeding time was 18 min. It was determined that this abnormal value was related to the chronic use of valproic acid as it will impair platelet aggregation. One pack of pooled platelets was administered prior to induction of anesthesia to correct this abnormality. Before induction, a right radial arterial catheter was inserted. An arterial blood gas (ABG) showed pH 7.38. $\mathrm{PCO}_{2} 42 \mathrm{mmHg}$. $\mathrm{PO}_{2} 72 \mathrm{mmHg}, \mathrm{HCO}_{3}{ }^{-} 25$ $\mathrm{mEq} \cdot \mathrm{L}^{-1}, \mathrm{O}_{2}$ Sat $97 \%$ breathing room air. Premedication was midazolam $1 \mathrm{mg}$ intravenously (iv).

Anaesthesia was induced with thiopentone $250 \mathrm{mg} i v$. Vecuronium $6 \mathrm{mg} i v$ was given to facilitate laryngoscopy. A central venous pressure (CVP) cannula was placed in the right internal jugular vein and showed an initial value of $12 \mathrm{mmHg}$. Anaesthesia was maintained with fentanyl and a mixture of oxygen, nitrous oxide and enflurane. Urine output was adequate throughout the procedure. The estimated blood loss was $2500 \mathrm{ml}$ and fluids administered included $5750 \mathrm{ml}$ lactated Ringer's (LR) solution, $1000 \mathrm{ml}$ Hetastarch, $500 \mathrm{ml}$ autologous blood and $1150 \mathrm{ml}$ of homologous packed red blood cells (PRBC). Neuromuscular blockade was reversed with neostigmine and glycopyrrolate. The trachea was extubated in the operating room without difficulty.

Thirty minutes after arriving in the recovery room the patient was receiving $\mathrm{O}_{2}$ by mask. Blood gas analysis revealed $\mathrm{pH}$ 7.29. $\mathrm{PCO}_{2} 41 \mathrm{mmHg}$. $\mathrm{PO}_{2} 89 \mathrm{mmHg}$. $\mathrm{HCO}_{3}{ }^{-} 20 \mathrm{mEq} \cdot \mathrm{L}^{-1}, \mathrm{O}_{2}$ Sat $95 \%$, and haematocrit (HCT) $25 \%$ with $\mathrm{FIO}_{2} 0.35$. A blood pressure of $90 / 40 \mathrm{mmHg}$ and a central venous pressure of $2 \mathrm{mmHg}$ were noted. The urine output was also decreased from that in the operating room. She was transfused one unit PRBC's and $500 \mathrm{ml}$ LR. Forty minutes later, the $\mathrm{pH}$ was $7.29, \mathrm{PCO}_{2} 43$ $\mathrm{mmHg}, \mathrm{PO}_{2} 90 \mathrm{mmHg}, \mathrm{HCO}_{3}{ }^{-} 21 \mathrm{mEq} \cdot \mathrm{L}^{-1}$, and $\mathrm{O}_{2}$ Sat $96 \%$ and $\mathrm{Hct} 24 \%$. The central venous pressure continued to be low, ranging from 0 to $2 \mathrm{mmHg}$. The patient then received another unit $P R B C$.

The wound drain was connected to a sterile re-infusion device which had accumulated an ongoing loss of $520 \mathrm{ml}$ blood. At this time, the patient had an arterial blood pressure of $78 / 34 \mathrm{mmHg}$ central venous pressure of 1 $\mathrm{mmHg}$ and a heart rate of $94 \mathrm{bpm}$. Blood, $420 \mathrm{ml}$, from the reinfusion system was administered by peripheral $i v$ over 20-30 min. During the transfusion, arterial blood gas analyses showed $\mathrm{pH}$ 7.26. $\mathrm{PCO}_{2} 45 \mathrm{mmHg}, \mathrm{PO}_{2} 112$ $\mathrm{mmHg}, \mathrm{HCO}_{3}^{-} 20 \mathrm{mEq} \cdot \mathrm{L}^{-1}$, and $\mathrm{O}_{2}$ Sat $98 \%$ with $\mathrm{FIO}_{2}$ 0.35 by mask. Immediately after autologous transfusion, the patient was unable to speak, breathless, tachypnoeic and the $\mathrm{O}_{2}$ Sat had decreased to $89 \%$. Marked head and neck oedema were noted. The trachea was intubated with a $7.0 \mathrm{~mm}$ oral tracheal tube and the lungs were ventilated with a mechanical ventilator. Severe airway oedema which included the epiglottis and laryngeal structures was noted during direct laryngoscopy. A blood gas revealed $\mathrm{pH}$ $7.26, \mathrm{PCO}_{2} 43 \mathrm{mmHg}, \mathrm{PO}_{2} 359 \mathrm{mmHg}, \mathrm{HCO}_{3}{ }^{-} \mathrm{mEq} \cdot \mathrm{L}^{-1}$ and $\mathrm{O}_{2}$ Sat $100 \%$ with $\mathrm{FIO}_{2}$ 1.0. Heart rate was $104 \mathrm{bpm}$, blood pressure $72 / 45 \mathrm{mmHg}$ and the CVP was $6 \mathrm{mmHg}$. Urine output continued to be minimal and was very concentrated in appearance. Ringer's lactate solution $(1000 \mathrm{ml})$ was administered and the haemodynamic status stabilized. Further investigation showed a prothrombin time (PT) of $18 \mathrm{sec}$ (normal 10-12) and a partial thromboplastin time (PTT) of $68 \mathrm{sec}$ (normal 21-35), fibrinogen of 59 (normal $>200 \mathrm{mg} \cdot \mathrm{DL}^{-1}$ ), bleeding time greater than $20 \mathrm{~min}$, and fibrin split products were moderately elevated. Also, intermittent left bundle branch block was noted. She was given fresh frozen plasma, cryoprecipitate, and pooled platelets. Her pulmonary and haemodynamic function remained stable and weaning from the ventilator was initiated. Ten hours later, blood gas analysis showed $\mathrm{pH} 7.40, \mathrm{PCO}_{2} 42 \mathrm{mmHg}, \mathrm{PO}_{2} 113 \mathrm{mmHg}$, $\mathrm{HCO}_{3}{ }^{-} 24 \mathrm{mEq} \cdot \mathrm{L}^{-1}$, and $\mathrm{O}_{2}$ Sat $98 \%, \mathrm{FIO}_{2} 0.35$. The PT was $12.7 \mathrm{sec}$ and PTT $29.2 \mathrm{sec}$. The trachea was extubated $18 \mathrm{hr}$ after surgery without incident. Two days later the patient was discharged from the hospital in satisfactory condition and had no pulmonary sequelae.

\section{Discussion}

This case demonstrated an acute transfusion reaction which may have been related to the administration of unwashed shed blood. In 1983, Popovsky et al. ${ }^{9}$ described five cases of non-cardiogenic pulmonary oedema in which blood transfusion was closely associated with respiratory compromise. They found leukoagglutinins in the donor blood as a possible cause of the event. This should not occur with autologous transfusion.

Complement-induced granulocyte aggregation has been reported as a mechanism to explain noncardiogenic pulmonary oedema ${ }^{10}$ and complement cascade activation by wound blood reinfusion systems was recently reported by Bengston et al. ${ }^{11}$ They showed elevations of $\mathrm{C} 3 \mathrm{a}$ and C5a fragments in wound drainage blood. Although these anaphylatoxins were found to be elevated, no patients in their series had any clinical effects. This absence of physiological alteration in their patients may be explained by their small sample size or the relative volume of blood reinfused. It has also been shown that cellophane, silicone 
polymer, endotoxin, inulin, and nylon fibres all have the potential to activate the complement cascade. ${ }^{12}$ These substances activate the cascade via the alternate pathway, causing the formation of $\mathrm{C} 5 \mathrm{a}$ fragments which cause agglutination of leukocytes. ${ }^{13}$ Leukocyte aggregates release toxic substances such as superoxide and hydrogen peroxide which cause endothelial damage resulting in capillary leak in vascular beds including the lung and upper airway. The reinfusion system consisted of tubing from a wound drain into a collection reservoir under continuous suction, Once a predetermined volume had accumulated in the reservoir, the blood was drained into a bag and retransfused into an intravenous line without opening the system. The reinfusion system contains numerous silicone-coated components and filters which could have activated the complement cascade,

Pulmonary capillary leak has been reported as a result of the use of methylmethacrylate in orthopaedic procedures. ${ }^{6.814}$ Although methylmethacrylate was used in our case, a temporal relationship with this event did not exist. Methylmethacrylate-induced noncardiogenic pulmonary oedema occurs shortly after its administration.

Bull et al. ${ }^{15}$ described a dog model which showed the effect of red cell salvage equipment on coagulation status and leukocyte aggregation. In their study, red blood cells were reinfused into dogs after washing. Aliquots exposed to the centrifuge bowl wall deposits had altered coagulation properties. This suspension also caused aggregation of leukocytes in lung parenchyma as seen by histological sections from the canine lung. They concluded that activation of platelets within the red cell salvage equipment may produce a heavy centrifuge bowl deposit, which could release toxic substances resulting in a procoagulant state and leukocyte aggregation in the lungs. It is possible that platelet activation within the reinfusion system could produce such a deposit on the walls of the collection reservoir and release similar toxic substances. Autologous blood transfusion reaction seems unlikely, but the previously described mechanisms support the theoretical possibility.

This case demonstrates the acute effects of a possible transfusion reaction after autologous blood. Treatment consisted of emergency intubation and controlled ventilation. Abnormal coagulation variables and fluid balance were corrected with fluid, blood and components. Subsequent blood cross-matching was not difficult. We cannot eliminate the possibility that this reaction occurred in response to one of the homologous units of packed cells despite the temporal relationship with the autologous transfusion.

In conclusion, we present a patient who developed a capillary leak phenomenon immediately after the administration of unwashed red cells from a wound reinfusion system. Platelet or complement activation was the speculative aetiology. The safety of autologous blood transfusion is questionable when blood is processed through a red cell salvage device without washing.

\section{References}

1 Levy GJ, Shabot MM, Hart ME, Mya WW, Goldfinger $D$. Transfusion-associated noncardiogenic pulmonary edema. Transfusion 1986; 26: 278-81.

2 Popovsky MA, Moore SB. Diagnostic and pathogenetic considerations in transfusion-related acute lung injury. Transfusion 1985; 25: 573-7.

3 Culliford AT, Thomas S, Spencer FC. Fulminating noncardiogenic pulmonary edema. J Thorac Cardiovasc Surg 1980; 80: 868-75.

4 Ebert JP, Grimes B, Niemann KMW. Respiratory failure secondary to homologous blood transfusion. Anesthesiology 1985; 63: 104-6.

5 Latson TW, Kickler TS, Baumgartner WA. Pulmonary hypertension and noncardiogenic pulmonary edema following cardiopulmonary bypass associated with an antigranulocyte antibody. Anesthesiology 1986; 64: 106-11.

6 Lewis RW, Rudd N, Pittman JA. Blood transfusion complications: leukoagglutinin reactions. Obstet Gynecol 1985; 65: 785-805.

$7 O^{\prime}$ Connor JC, Strauss RG, Goeken NE, Knox LB. A nearfatal reaction during granulocyte transfusion of a neonate. Transfusion 1988; 28: 173-6.

8 Fitzgerald J, Chatwani A, Oyer R. Noncardiogenic pulmonary edema as a rare complication of blood transfusions. J Reprod Med 1988; 33: 243-5.

9 Popovsky MA, Marlin DA, Moore SB. Transfusion-related acute lung injury associated with passive transfer or antileukocyte antibodies. Am Rev Respir Dis 1983; 128: 185-9.

10 Hammerschmidt DE, Jacob HS. Adverse pulmonary reactions to transfusion. Adv Intern Med 1982; 27: 511-30.

11 Bengtson J, Backman L, Stenquist O, Heideman $M$, Bengtsson A. Complement activation and reinfusion of wound drainage blood. Anesthesiology 1990; 73: 376-80.

12 Jacob HS, Craddock PR, Hammerschmidt DE, Moldow $C F$. Complement-induced granulocyte aggregation. $\mathrm{N}$ Engl J Med 1980; 302: 789-94.

13 Greenburg CS. Atheroma cholesterol actuates complement and aggregates granulocytes. Trans Assoc Am Physicians 1979; 92: 130-5.

14 Safwat $A M$, Dror $A$. Pulmonary capillary leak associated with methylmethacrylate during general anesthesia. Clin Orthop 1982; 168: 59-63.

15 Bull MH, Bull BS, Van Arsdell GS, Smith LL. Clinical implications of procoagulant and leukoattractant formation during intraoperative blood salvage. Arch Surg 1988; 123: 1073-8. 